\title{
The impact of a tax on sugar-sweetened beverages according to socio-economic position: a systematic review of the evidence
}

\author{
Kathryn Backholer ${ }^{1,2, *}$, Danja Sarink ${ }^{1}$, Alison Beauchamp ${ }^{2}$, Catherine Keating ${ }^{1}$, \\ Venurs Loh ${ }^{3}$, Kylie Ball ${ }^{4}$, Jane Martin ${ }^{5}$ and Anna Peeters ${ }^{1,2}$ \\ 'Obesity and Population Health, Baker IDI Heart and Diabetes Institute, Level 4, 99 Commercial Road, Melbourne, \\ Victoria 3004, Australia: ${ }^{2}$ Centre for Population Health Research, School of Health and Social Development, Deakin \\ University, Victoria, Australia: ${ }^{3}$ School of Public Health and Social Work/Institute of Health and Biomedical \\ Innovation, Queensland University of Technology, Brisbane, Queensland, Australia: ${ }^{4}$ Centre for Physical Activity and \\ Nutrition Research, School of Exercise and Nutrition Sciences, Deakin University, Victoria, Australia: ${ }^{5}$ Obesity Policy \\ Coalition, Melbourne, Victoria, Australia
}

Submitted 5 November 2015: Final revision received 22 March 2016: Accepted 1 April 2016: First published online 16 May 2016

\begin{abstract}
Objective: A tax on sugar-sweetened beverages (SSB) has been proposed to address population weight gain but the effect across socio-economic position (SEP) is unclear. The current study aimed to clarify the differential impact(s) of SSB taxes on beverage purchases and consumption, weight outcomes and the amount paid in SSB taxes according to SEP.

Design: Databases (OVID and EMBASE) and grey literature were systematically searched in June 2015 to identify studies that examined effects of an SSB price increase on beverage purchases or consumption, weight outcomes or the amount paid in tax across SEP, within high-income countries.

Results: Of the eleven included articles, three study types were identified: (i) those that examined the association between variation in SSB taxes and SSB consumption and/or body weight ( $n$ 3); (ii) price elasticity estimation of SSB demand ( $n$ 1); and (iii) modelling of hypothetical SSB taxes by combining price elasticity estimates with population SEP-specific beverage consumption, energy intake or body weight $(n 7)$. Few studies statistically tested differences in outcomes between SEP groups. Nevertheless, of the seven studies that reported on changes in weight outcomes for the total population following an increase in SSB price, all reported either similar reductions in weight across SEP groups or greater reductions for lower compared with higher SEP groups. All studies that examined the average household amount paid in $\operatorname{tax}(n 5)$ reported that an SSB tax would be regressive, but with small differences between higher- and lower-income households $(0 \cdot 10-1.0 \%$ and $0.03 \%-0.60 \%$ of annual household income paid in SSB tax for low- and high-income households, respectively).

Conclusions: Based on the available evidence, a tax on SSB will deliver similar population weight benefits across socio-economic strata or greater benefits for lower SEP groups. An SSB tax is shown to be consistently financially regressive, but to a small degree.
\end{abstract}

Keywords Sugar-sweetened beverage Socio-economic inequalities Obesity Policy
The prevalence of obesity follows a socio-economic pattern. In high-income countries, individuals with a lower income, a lower education or who live in more disadvantaged areas are at a higher risk for excess weight gain and obesity ${ }^{(1,2)}$. Accordingly, it was recommended in the 2010 UK Fair Societies, Healthy Lives report that evidence-based, universal interventions that address the causes of obesity across the socio-economic gradient be implemented $^{(3)}$. However, very few obesity prevention interventions are evaluated according to their impact across socio-economic strata ${ }^{(4-7)}$.

A tax on sugar-sweetened beverages (SSB) features prominently in the suite of recommended regulatory approaches to address population weight gain $^{(8-11)}$. Evidence demonstrates that regular consumption of SSB is associated with excess weight gain and a number of 
co-morbid conditions ${ }^{(12)}$, including diabetes, CVD and dental caries ${ }^{(13)}$. Moreover, SSB lack nutritional value and, in the absence of satiety signals, commonly represent excess energy in the daily diet ${ }^{(14,15)}$. Individuals from lower socio-economic groups commonly consume more SSB than their higher socio-economic counterparts ${ }^{(16,17)}$, potentially contributing to the observed inequalities in excess weight and associated disease. Finally, SSB are consumed in relatively high quantities (in 2012, $26 \cdot 3 \%$ of US adults consumed SSB one or more times daily ${ }^{(18)}$ ) leading to greater price sensitivity compared with products consumed at low frequencies and volumes ${ }^{(19)}$.

Although several high-income countries around the world already have a tax on SSB, these are often small in magnitude (e.g. across all US states, SSB taxes average approximately $\left.4 \%^{(11)}\right)$ and are implemented for revenue-, rather than health-related reasons. The latter is important as a tax implemented for health-related reasons is likely to additionally act as a health communication campaign. In 2014, Mexico became the first country to impose a national health-related excise tax on beverages with added sugar of 1 peso per litre (approximately a 10\% price increase). Recent evaluation of the tax revealed a reduction in the purchase of sugary drinks of $12 \%, 12$ months post policy implementation, compared with the counterfactual scenario based on pre-tax trends ${ }^{(20)}$. In that study, the greatest declines were observed among households of a lower socioeconomic position (SEP), with a 12-month decline in sugary drinks of $17 \%$ compared with pre-tax trends ${ }^{(20)}$.

Price elasticity estimates of SSB demand suggest that a $10 \%$ tax on SSB could lead to an $8-10 \%$ reduction in the purchase of these beverages ${ }^{(21)}$. Modelling studies further predict that a $20 \%$ tax on SSB in the USA could reduce the prevalence of obesity by 3.5 percentage points ${ }^{(22)}$. However, one of the major concerns about a tax on SSB is that it will be financially regressive, whereby those with a lower income would pay a greater proportion of their income in tax compared with higher income earners ${ }^{(23)}$. Proponents, on the other hand, argue that this financial regressivity would be justified by the progressive health benefits (greater for those with a lower SEP) given the higher obesity prevalence and greater consumption of SSB among lower socio-economic groups ${ }^{(23)}$.

Although several studies have synthesised the impacts of an SSB tax according to SEP, these studies are usually limited to include specific study designs, single outcomes and do not consider the differential amounts paid in SSB tax as a proportion of income. Understanding the health equity impact of an SSB tax is essential if we wish to prioritise obesity prevention interventions that are most likely to be effective across all socio-economic strata. The aim of the present work was to systematically review the literature for studies (of any study design) conducted in high-income countries that examined the effect of an SSB price increase on beverage purchase or consumption and/ or weight outcomes according to an indicator of SEP.
Where possible, we additionally aimed to examine the average amount paid in SSB tax across socio-economic strata (as a percentage of income).

\section{Methods}

We conducted a systematic review of the literature to identify studies from high-income countries that reported on one or more of the following outcomes: beverage purchases, beverage consumption (and/or total energy intake) and/or weight outcomes following a change in SSB price according to a marker of SEP. Low- and middleincome countries were excluded due to the relationship between SEP and SSB intake and/or obesity being the reverse (or a varying relationship as a result of undergoing nutritional transition) of that which is consistently observed in high-income countries. From these studies, we were additionally interested in the data pertaining to the amount paid in tax for each SEP group. Because a regressive tax is one where the poor pay a higher percentage of their income in tax compared with the rich, we intended only to include studies where the proportion of income paid in SSB tax across SEP was reported. However, we were also able to include studies that reported only on the absolute amount paid in SSB tax across income groups as these studies reported a greater absolute amount paid in tax among lower-income households, which necessarily equates to a greater proportion of household income.

A protocol was developed for the selection, analysis and reporting of articles in accordance with the Preferred Reporting Items for Systematic Reviews and Meta-Analysis Equity (PRISMA-Equity) guidelines ${ }^{(24)}$. Relevant information was extracted from all included studies, including the impact of an SSB price change on beverage purchase and consumption and weight outcomes, as well as the amount paid in tax for all socio-economic groups. Finally, the overall quality of the study was assessed (see below) and the robustness of conclusions evaluated. Due to the heterogeneity in the outcome reported across studies, and therefore a small number of studies for each outcome, we did not examine risk of publication bias.

\section{Search strategy}

Electronic databases (Medline via OVID and EMBASE) and grey literature (System for Information on Grey Literature in Europe, the Virtual Library for Public Health, Google Scholar, plus websites and reports from relevant organizations, including those with a health equity focus) were systematically searched from database inception to June 2015 to identify studies (any study design) that included terms for SSB, taxation and SEP. Each hedge (SSB, taxation and SEP) was combined with the operator 'AND' and within each hedge, search terms were combined using the operator 'OR'. Specific search terms were as follows (used as 
keywords unless otherwise stated): SSB (soda, soft drink, carbonated beverage*, sugar-sweetened*, beverage*, beverages/economics (Medical Subject Heading (MeSH)); taxation (price*, subsid*, cost*, tax*, demand elast*, taxes/ economics (MeSH)); SEP (income, education*, disadvantage, disparit*, equit*, inequal*, inequit*, occupation, socio*, socioeconomic factors (MeSH), social class (MeSH)). Use of an asterisk denotes an open-ended search term. No limits were placed on the basis of language, country or publication date. The reference lists of all relevant original research and review articles were scanned to capture citations missed by electronic searches. Authors were contacted for missing information.

All retrieved articles were independently scanned in three stages by two reviewers (K.B. and V.L.). First, studies were assessed for relevance of title. If the title appeared relevant, or if authors were unsure, the abstract was next assessed to determine if the study satisfied the inclusion criteria. Included or unclear articles then proceeded to the full manuscript stage to be formally assessed against the inclusion criteria.

\section{Inclusion criteria and data extraction}

Studies were included if they reported on the impact of a change in SSB price on beverage purchase or consumption, energy intake and/or body weight outcomes (or another marker of adiposity) according to any marker of SEP (individual- or area-based) within a high-income country.

A matrix table of study characteristics was compiled and the relevant information was extracted from the included articles by two independent authors with disagreements resolved by consensus with other authors. In the few instances where relative consumption or weight outcomes (percentage reduction) were reported we also calculated absolute effects (percentage-point reduction) and present both. Where possible we also converted units of results to the most commonly reported unit for consistency across studies. Study authors were contacted where relevant information was missing.

\section{Quality of studies}

We assessed the quality of all studies using a checklist derived from two recent reviews of food and beverage pricing studies ${ }^{(25,26)}$. The quality criteria assessed were: (i) prospective study of observed behaviour; (ii) evaluation of an actual tax (rather than a hypothetical tax); (iii) price linked directly to purchase within the same population; (iv) consideration of product compensation (cross-price elasticity; CPE); (v) long-run input data across time with sufficient variation in prices used to estimate price elasticities (for experimental studies this included data collected over a period of at least one month, for studies using existing data sets on SSB price this included data collected at intervals no less than two months apart for at least 12 months); (vi) valid and appropriate countryspecific data; and (vii) reporting of uncertainty around price elasticity estimates. We report on all quality criteria for all studies and rate each study out of 7 , reflecting 1 point for each quality measure. A sensitivity analysis was performed on studies that scored $\geq 4$ points.

\section{Results}

\section{Study characteristics}

The literature search identified 270 articles in total. After screening for inclusion criteria, eleven articles were selected to be included in the synthesis of evidence (see Fig. 1 for a flowchart of the search strategy). A summary of the study characteristics and the likely effect of an SSB price change on differences by SEP in SSB purchase, consumption or weight outcomes and the tax burden as a result of an SSB tax are presented in Table 1. Briefly, seven studies used data from the USA, with one study from each of the UK, Ireland, Australia and New Zealand. Ten studies used income as an indicator of SEP (nine of these used household income and one used individual income) and one study in adolescents used parental education. Three principal study types were identified: (i) those that examined the association between variation in SSB taxes across US states and individual SSB consumption and/or BMI ( $\left.n 3^{(27-29)}\right)$; (ii) price elasticity estimation of SSB demand from household food and beverage price and expenditure data $\left(n 1^{(30)}\right)$; and (iii) modelling to simulate the impact of a hypothetical SSB tax by combining price elasticity estimates with population data on the SEP-specific patterning of beverage consumption, net energy intake or body weight outcomes $\left(n 7^{(22,31-36)}\right)$. Four of the seven modelling studies used similar data from the USA (with some overlap of sampling period) ${ }^{(22,31,32,36)}$; however, model specifications and input parameters differed markedly between studies. Six of the eleven included studies received a score of $\geq 4$ points (out of 7) for quality

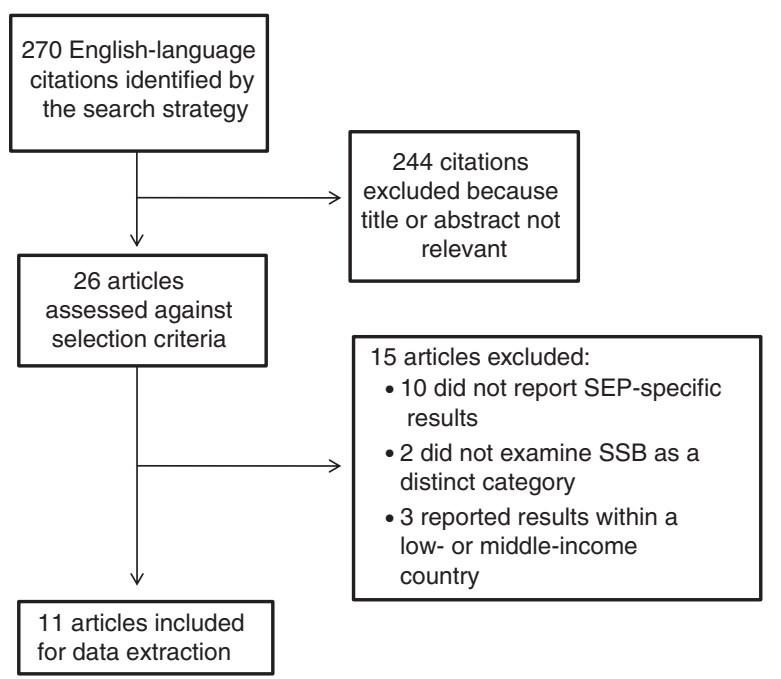

Fig. 1 Flowchart of the search strategy (SEP, socio-economic position; SSB, sugar-sweetened beverage) 


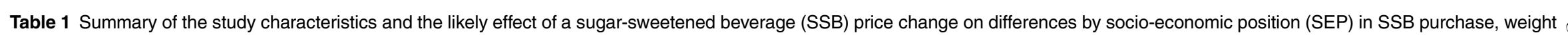
benefits and/or tax burden as a result of an SSB tax

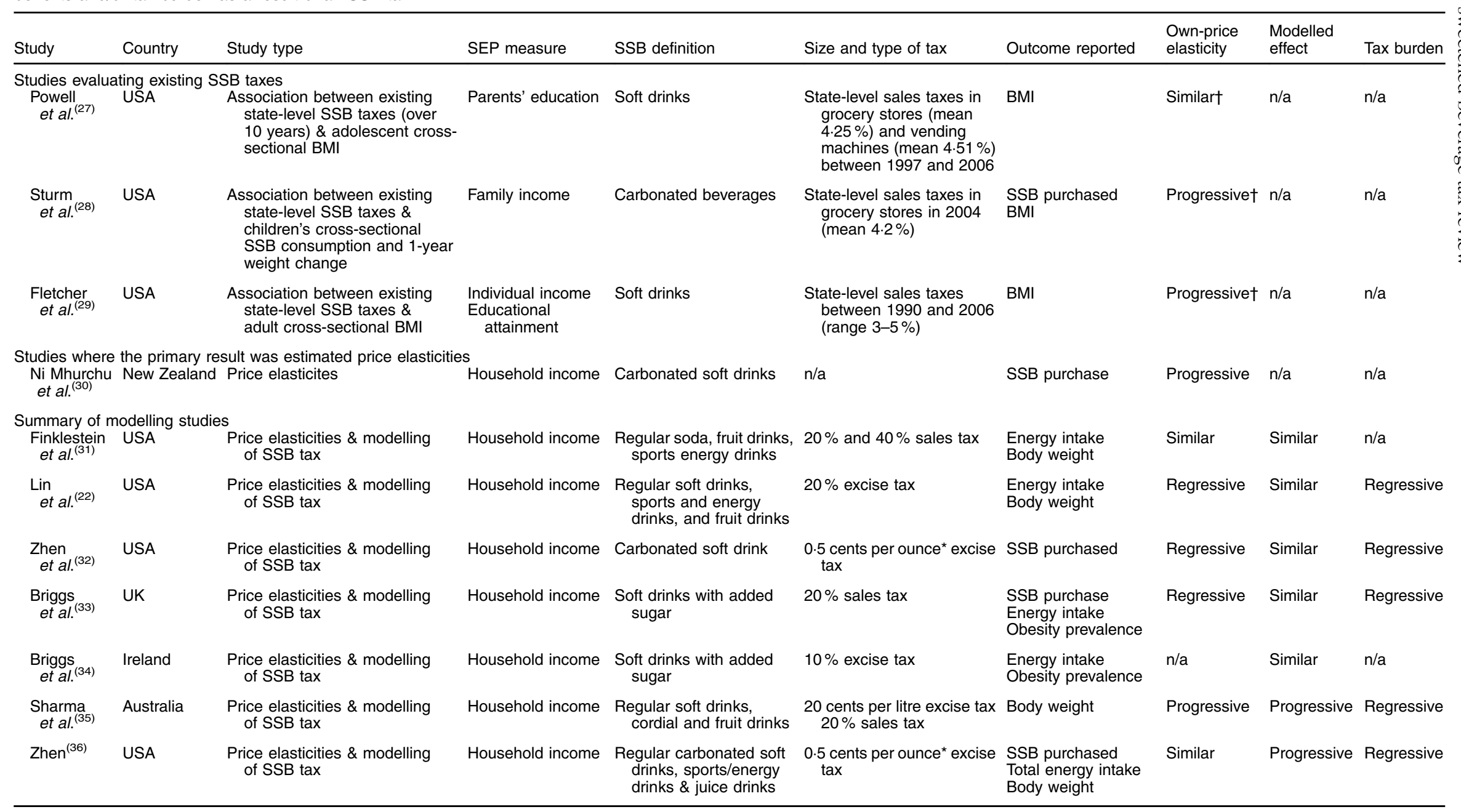

n/a, not applicable.

'Progressive' refers to when the effect sizes are greater groups compared with lower socio-economic groups.

†These studies did not estimate own-price elasticities: Powell et al. reported no association between state-level SSB taxes and adolescent BMl across income categories; Sturm et al. reported that lower existing SSB tax rates were associated with less SSB consumplio 
appraisal $^{(22,31-33,35,36)}$ (Table 2). Few studies statistically tested differences in outcomes between SEP groups.

Results (point estimates, variance and when tested, significance) are outlined below and in Table 3 for all eleven of the included studies (analysis of only those studies scoring $\geq 4$ points in quality appraisal revealed similar conclusions). Details of the data sets used and the general methods employed for each study can be found in the online supplementary material.

\section{Beverage purchase, consumption and weight impacts of a sugar-sweetened beverage tax according to socio-economic position}

Studies evaluating existing sugar-sweetened beverage taxes Three studies examined the association between variations in state-level SSB taxes (average of $4 \%$ ) across the USA and individual-level SSB consumption and/or BMI according to a marker of SEP.

Powell et $a l^{(27)}$ reported no relationship between variation in SSB taxes and adolescents' BMI for any parental education group. In the study by Sturm et ll $^{(28)}$ associations between variations in existing SSB tax rates and SSB consumption and BMI were examined for the entire population and for children from low-income households. For the whole population, no association was observed between SSB taxes and overall SSB consumption or mean BMI change. However, among children from low-income families, a 1 percentage point increase in the SSB tax rate (in excess of other food items) resulted in a significant reduction in the total number of SSB consumed of $0 \cdot 142$ SSB/week. A 1 percentage point higher differential SSB tax rate was also associated with a significant reduction in BMI of $0.013 \mathrm{~kg} / \mathrm{m}^{2}$ between the third and fifth grades for the total population, but this did not hold up under all statistical analyses. For low-income populations higher tax rates were not associated with a significant reduction in BMI; however, the authors noted that reduced statistical power limited the results from subgroup analyses. Fletcher et al. ${ }^{(29)}$ reported a stronger relationship between variation in SSB taxes and weight outcomes for adults with lower (compared with higher) income and for those with a higher (compared with a lower) education level. Between 1990 and 2006, a 1 percentage point increase in existing SSB tax rates was associated with a significant $0.015 \mathrm{~kg} / \mathrm{m}^{2}$ reduction in BMI for low-income adults and a $0.008 \mathrm{~kg} / \mathrm{m}^{2}$ decrease in BMI for high-income adults. When using education as the SEP indictor, a 1 percentage point increase in the SSB tax rate was associated with a significant $0.0031 \mathrm{~kg} / \mathrm{m}^{2}$ and $0.0076 \mathrm{~kg} / \mathrm{m}^{2}$ reduction in BMI for high-school graduates and college graduates, respectively.

Studies where the primary result was estimated price elasticities

One study estimated the income-specific change in SSB demand following a change in SSB price (own-price elasticity; OPE) in New Zealand ${ }^{(30)}$. In that study, lower-income

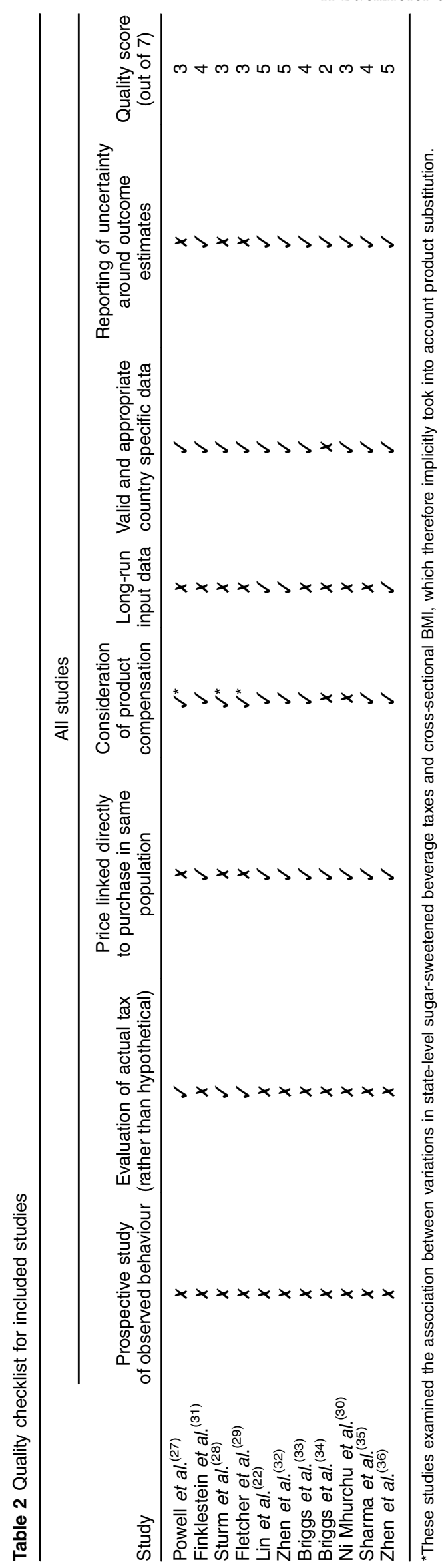




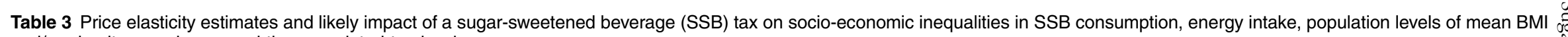
and/or obesity prevalence, and the associated tax burden

\begin{tabular}{|c|c|c|c|c|c|c|c|}
\hline \multirow[b]{2}{*}{ Study } & \multirow[b]{2}{*}{ Price elasticities } & \multirow[b]{2}{*}{ Size and type of tax } & \multicolumn{5}{|c|}{ Modelled effects of hypothetical SSB tax or relationship with existing state-level SSB taxes } \\
\hline & & & Consumption & Energy intake & Weight or BMl & Obesity prevalence & Tax burden \\
\hline \multicolumn{8}{|c|}{ Studies evaluating existing SSB taxes } \\
\hline Powell et al. ${ }^{(27)}$ & $\mathrm{n} / \mathrm{a}$ & $\begin{array}{l}\text { State-level SSB sales } \\
\text { taxes in grocery stores } \\
\text { (mean } 4 \cdot 25 \% \text { ) and } \\
\text { vending machines } \\
\text { (mean } 4.51 \% \text { ) }\end{array}$ & $\mathrm{n} / \mathrm{a}$ & $\mathrm{n} / \mathrm{a}$ & $\begin{array}{l}\text { No significant association } \\
\text { between variation in } \\
\text { state-level SSB taxes } \\
\text { and adolescent BMI } \\
\text { across any parental } \\
\text { education categories }\end{array}$ & $\mathrm{n} / \mathrm{a}$ & $\mathrm{n} / \mathrm{a}$ \\
\hline Sturm et al. ${ }^{(28)}$ & $\mathrm{n} / \mathrm{a}$ & $\begin{array}{l}\text { State-level SSB sales } \\
\text { taxes in grocery stores } \\
\text { (mean } 4 \cdot 2 \% \text { ) }\end{array}$ & $\begin{array}{l}\text { No significant association } \\
\text { between existing state- } \\
\text { level SSB taxes and } \\
\text { children's SSB } \\
\text { consumption for the total } \\
\text { population. For children } \\
\text { from low-income families, } \\
\text { for every } 1 \% \text { higher tax } \\
\text { rate across states (over } \\
\text { and above the tax on } \\
\text { other foods within the } \\
\text { state) there was a } 0.142^{*} \\
\text { and } 0.039^{*} \text { reduction in } \\
\text { the total drinks/week } \\
\text { consumed and drinks/ } \\
\text { week consumed at } \\
\text { school, respectively }\end{array}$ & $\mathrm{n} / \mathrm{a}$ & $\begin{array}{l}\text { No significant association } \\
\text { between variation in } \\
\text { state-level SSB taxes } \\
\text { and children's BMI for } \\
\text { any income groups }\end{array}$ & $\mathrm{n} / \mathrm{a}$ & $\mathrm{n} / \mathrm{a}$ \\
\hline $\begin{array}{l}\text { Fletcher } \\
\text { et al. }{ }^{(29)}\end{array}$ & $\mathrm{n} / \mathrm{a}$ & $\begin{array}{l}\text { State-level SSB sales } \\
\text { taxes (range 3-5\%) }\end{array}$ & $\mathrm{n} / \mathrm{a}$ & $\mathrm{n} / \mathrm{a}$ & $\begin{array}{l}\text { A } 1 \% \text {-point increase in } \\
\text { existing SSB tax rates } \\
\text { was associated with a } \\
0.015 \mathrm{~kg} / \mathrm{m}^{2 *} \text { reduction } \\
\text { in } \mathrm{BMI} \text { for low-income } \\
\text { adults and a } 0.008 \mathrm{~kg} / \\
\mathrm{m}^{2 *} \text { decrease in BMl for } \\
\text { high-income adults } \\
\text { The corresponding } \\
\text { reductions were } \\
0.0031 \mathrm{~kg} / \mathrm{m}^{2 *} \text { and } \\
0.0076 \mathrm{~kg} / \mathrm{m}^{2 *} \text { for high- } \\
\text { school graduates and } \\
\text { college graduates, } \\
\text { respectively }\end{array}$ & $\begin{array}{l}\text { A } 1 \% \text {-point increase in } \\
\text { existing SSB tax rates was } \\
\text { associated with a } 0.08 \%- \\
\text { point } \text { reduction in obesity }^{*} \text { and a } 0.1 \% \text {-point } \\
\text { reduction in overweight for } \\
\text { low-income adults and a } \\
0.05 \% \text {-point }{ }^{\star} \text { and } 0.08 \%- \\
\text { point } \text { reduction in obesity } \text { and overweight, } \\
\text { respectively, for high- } \\
\text { income adults } \\
\text { The corresponding } \\
\text { reductions were } 0.02^{\star} \text { and } \\
0.02 \%-\text { points }{ }^{*} \text { for high- } \\
\text { school graduates and } \\
0.044^{*} \text { and } 0.04 \%-\text { points } \\
\text { for college graduates, } \\
\text { respectively }\end{array}$ & $\mathrm{n} / \mathrm{a}$ \\
\hline \multicolumn{8}{|c|}{ Studies where the primary result was estimated price elasticities } \\
\hline $\begin{array}{l}\text { Ni Mhurchu } \\
\text { et al. }{ }^{(30)}\end{array}$ & $\begin{array}{l}\text { OPE for carbonated soft } \\
\text { drinks (SE) } \\
\text { Q1:-2.20 (1.16) } \\
\text { Q2: }-3.47(0.99) \\
\text { Q3: }-0.14(0.43) \\
\text { Q4: }-2.95(0.52) \\
\text { Q5: }-1.26(0.44) \\
\text { No statistically significant } \\
\text { difference in OPE } \\
\text { between Q1 \& Q5 }\end{array}$ & $\mathrm{n} / \mathrm{a}$ & $\mathrm{n} / \mathrm{a}$ & $\mathrm{n} / \mathrm{a}$ & $\mathrm{n} / \mathrm{a}$ & $\mathrm{n} / \mathrm{a}$ & $\mathrm{n} / \mathrm{a}$ \\
\hline
\end{tabular}


Modelled effects of hypothetical SSB tax or relationship with existing state-level SSB taxes

\begin{tabular}{|c|c|c|c|c|c|c|c|}
\hline \multirow[b]{2}{*}{ Study } & \multirow[b]{2}{*}{ Price elasticities } & \multirow[b]{2}{*}{ Size and type of tax } & \\
\hline & & & Consumption & Energy intake & Weight or BMI & Obesity prevalence & Tax burden \\
\hline \multicolumn{8}{|c|}{ Summary of modelling studies } \\
\hline $\begin{array}{l}\text { Finkelstein } \\
\text { et al. }{ }^{(31)}\end{array}$ & $\begin{array}{l}\text { Carbonated SSB } \\
\text { Across all households } \\
\text { the OPE (sE) was } \\
-0.73(0.09)^{\star}, \text { with } \\
\text { estimates ranging from } \\
-1.02(0.17)^{\star} \text { for } \\
\text { households in the } 50- \\
75 \% \text { income quartile } \\
\text { to }-0.49(0.20)^{\star} \text { for the } \\
0-25 \% \text { income } \\
\text { quartile of households } \\
\text { All SSB } \\
\text { Income-specific OPE not } \\
\text { reported } \\
\text { CPE } \\
\text { Examined but not } \\
\text { reported }\end{array}$ & $\begin{array}{l}20 \% \text { or } 40 \% \text { sales tax on } \\
\text { carbonated SSB } \\
20 \% \text { or } 40 \% \text { sales tax on } \\
\text { all SSB }\end{array}$ & $\mathrm{n} / \mathrm{a}$ & $\begin{array}{l}20 \% \text { tax on carbonated SSB } \\
\text { (kcal/d) } ¥ \\
\text { No statistically significant } \\
\text { reduction in beverage } \\
\text { calories for households in } \\
\text { the lowest- and highest- } \\
\text { income quartiles. Across } \\
\text { all households beverage } \\
\text { purchases reduced by a } \\
\text { mean of } 4.2^{\star}, \text { which was } \\
\text { entirely driven by the } \\
\text { middle-income } \\
\text { households } \\
40 \% \text { tax on carbonated SSB } \\
\text { (kcal/d) } \neq \\
\text { Across all households } \\
\text { beverage purchases } \\
\text { reduced by a mean of } \\
7.8^{\star}, \text { which was entirely } \\
\text { driven by middle-income } \\
\text { households }\end{array}$ & 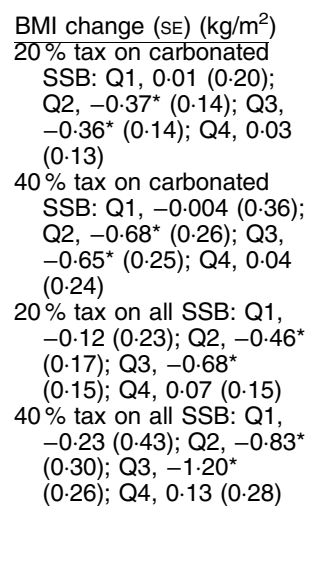 & $\mathrm{n} / \mathrm{a}$ & $\mathrm{n} / \mathrm{a}$ \\
\hline Lin et al. ${ }^{(22)}$ & $\begin{array}{l}\text { OPE (SE) } \\
\text { High income: }-1 \cdot 29 \\
(0.096)^{*} \\
\text { Low income: }-0.95 \\
(0.082)^{*} \\
\text { CPE } \\
\text { High income: significant } \\
\text { substitution for } \\
\text { skimmed milk, low-fat } \\
\text { milk, juice, bottled } \\
\text { water and significant } \\
\text { complementary } \\
\text { reduction in diet drinks } \\
\text { Low income: significant } \\
\text { substitution for juices } \\
\text { and complementary } \\
\text { reduction in diet drinks, } \\
\text { skimmed milk, low-fat } \\
\text { milk and whole milk }\end{array}$ & $20 \%$ excise tax & $\mathrm{n} / \mathrm{a}$ & $\begin{array}{l}\text { Change in energy intake } \\
\text { (kcal/d) } \\
\text { High income: } \\
\text { Adults, }-37 \text { from all } \\
\text { beverages, }-38 \text { from SSB } \\
\text { Children, }-45 \text { from all } \\
\text { beverages, }-50 \text { from SSB } \\
\text { Low income: } \\
\text { Adults, }-33 \text { from all } \\
\text { beverages, }-35 \text { from SSB } \\
\text { Children, }-33 \text { from all } \\
\text { beverages, }-36 \text { from SSB }\end{array}$ & $\begin{array}{l}\frac{10 \text {-year weight change }}{(\mathrm{kg} \text {, adults only }} \\
\text { High income: }-1.80 \\
\text { Low income: }-1.90\end{array}$ & $\begin{array}{l}\frac{10-y e a r}{\%} \text { change in } \\
\text { prevalence of obesity } \\
\text { (\%-points), adults only } \\
\text { High income: }-10.5(3.46) \\
\text { Low income: }-10.2(3.58)\end{array}$ & $\begin{array}{l}\text { Annual tax burden (\$US) } \\
\text { attributable to SSB tax } \\
\text { Low income: } 19.97 \\
\text { High income: } 18.84 \\
\text { SSB tax as } \% \text { of all food } \\
\text { and beverage } \\
\text { spending } \\
\text { Low income: } 1 \% \\
\text { High income: } 0.6 \%\end{array}$ \\
\hline Zhen et al. ${ }^{(32)}$ & $\begin{array}{l}\text { OPE for regular } \\
\text { carbonated soft drinks } \\
\text { Low-income households: } \\
-1.22 \text { (myopic), }-1.06 \\
\text { (rational) } \\
\text { High-income households: } \\
-1.44 \text { (myopic), }-1.54 \\
\text { (rational) }\end{array}$ & $\begin{array}{l}0.5 \text { cents per ounce } \dagger \\
\text { excise tax }\end{array}$ & $\begin{array}{l}\frac{\% \text { Long-run household }}{\text { change in monthly }} \\
\text { demand for regular } \\
\text { carbonated soft drinks } \\
\text { (reduction in ounces) } \\
\text { Low income: }-27 \cdot 4,-33.9 \\
(-82 \cdot 81,-102 \cdot 62) \\
\text { High income: }-34 \cdot 4,-35.6 \\
(-88.92,-92 \cdot 23)\end{array}$ & $\mathrm{n} / \mathrm{a}$ & $\mathrm{n} / \mathrm{a}$ & $\mathrm{n} / \mathrm{a}$ & $\begin{array}{l}\frac{\text { Annual tax burden (\$US) }}{(\% \text { of annual income) }} \\
\text { Low income: } \\
17.64-18.60(0.1) \\
\text { High income: } \\
\text { 15.84-16.92 (0.03) }\end{array}$ \\
\hline
\end{tabular}




\begin{tabular}{|c|c|c|c|c|c|c|c|}
\hline \multirow[b]{2}{*}{ Study } & \multirow[b]{2}{*}{ Price elasticities } & \multirow[b]{2}{*}{ Size and type of tax } & \multicolumn{5}{|c|}{ Modelled effects of hypothetical SSB tax or relationship with existing state-level SSB taxes } \\
\hline & & & Consumption & Energy intake & Weight or BMI & Obesity prevalence & Tax burden \\
\hline $\begin{array}{l}\text { Sharma } \\
\text { et al. }{ }^{(35)}\end{array}$ & $\begin{array}{l}\text { Income-specific OPE and } \\
\text { CPE estimated but not } \\
\text { explicitly reported; } \\
\text { however, it is noted } \\
\text { that high-income } \\
\text { households had the } \\
\text { least elastic demand } \\
\text { for regular soft drinks }\end{array}$ & $\begin{array}{l}20 \% \text { sales tax } \\
20 \text { cents per litre } \\
\text { excise tax }\end{array}$ & $\begin{array}{l}\% \text { Change in SSB } \\
\frac{\text { consumption per capita }}{\text { (reduction in ounces/ }} \\
\frac{\text { quarter)† }}{20 \% \text { sales tax: }} \\
\text { Low income, }-15 \cdot 05 \\
(-52 \cdot 1)^{\star} \\
\text { Middle income, }-14.92 \\
(-50 \cdot 7)^{\star} \\
\text { High income, }-13 \cdot 10 \\
(-35 \cdot 17)^{\star} \\
20 \text { cents per litre excise } \\
\text { tax: } \\
\text { Not reported by income }\end{array}$ & $\mathrm{n} / \mathrm{a}$ & $\begin{array}{l}\text { Weight change }(\mathrm{kg}) \\
20 \% \text { sales tax: } \\
\text { Low income, }-0.40 \\
\text { Middle income, }-0.37 \\
\text { High income, }-0.23 \\
20 \text { cents per litre excise } \\
\text { tax: } \\
\text { Low income, }-0.56 \\
\text { Middle income, }-0.69 \\
\text { High income, }-0.35 \\
\text { Differences between high- } \\
\text { and low-income groups } \\
\text { significant }^{\star}\end{array}$ & $\mathrm{n} / \mathrm{a}$ & $\begin{array}{l}\frac{\text { Annual per capita tax }}{\text { burden (\$AU) }} \\
\text { attributable to SSB tax } \\
\text { (\% of annual income) } \\
20 \% \text { sales tax: } \\
\text { Low income, } 20.89 \\
(0.22 \%) \\
\text { Middle income, } 17.74 \\
(0.07 \%) \\
\text { High income, } 16.60 \\
(0.03 \%) \\
20 \text { cents per litre excise } \\
\text { tax: } \\
\text { Low income, } 19.00 \\
(0.15 \%) \\
\text { Middle income, } 14.77 \\
(0.05 \%) \\
\text { High income, } 13.81 \\
(0.04 \%) \\
\text { Differences between } \\
\text { high- and low-income } \\
\text { groups significant }\end{array}$ \\
\hline Zhen et al. (36) $^{2}$ & $\begin{array}{l}\text { OPE } \\
\text { LOW-income households: } \\
-1.03^{*} \\
\text { High-income households: } \\
-1 \cdot 04^{*} \\
\text { CPE } \\
\text { Broadly similar across } \\
\text { income groups }\end{array}$ & $\begin{array}{l}0.5 \text { cents per ounce } \dagger \\
\text { excise tax }\end{array}$ & $\begin{array}{l}\text { Change in regular } \\
\frac{\text { carbonated soft drink }}{\text { consumed per capita, }} \\
\frac{\text { reduction in (ounces/ }}{\text { quarter) } \dagger} \\
\text { Low income: }-65.8 \\
\text { High income: }-49.3\end{array}$ & $\begin{array}{l}\text { Change in energy intake per } \\
\text { person (kcal/d) } \\
\text { Low income: }-13.2 \\
\text { High income: }-5 \cdot 6\end{array}$ & $\begin{array}{l}\text { Change in weight }(\mathrm{kg}) \\
\text { Low income: }-0.37 \text { in } 1 \\
\text { year and }-0.70 \text { in } 10 \\
\text { years } \\
\text { High income: }-0.16 \text { in } 1 \\
\text { year and }-0.31 \text { in } 10 \\
\text { years }\end{array}$ & $\mathrm{n} / \mathrm{a}$ & $\begin{array}{l}\text { Average tax burden of } \\
\text { approximately } \$ \text { US } 20 \\
\text { per year per } \\
\text { household with a } \\
\text { difference of } \\
\text { approximately \$US } 5 \\
\text { per household per } \\
\text { year between high- } \\
\text { and low-income } \\
\text { households }\end{array}$ \\
\hline
\end{tabular}

n/a, not applicable; OPE, own-price elasticity; CPE, cross-price elasticity; Q, quintile.

Significant effect size. Note: the significance of point estimates and differences between socio-economic groups are stated, otherwise significance not reported. Values in parentheses represent $95 \%$ confidence (or credible) intervals. For a given outcome, all values are converted to the most common unit reported across studies for comparison.

til. oz (US) $=29.574 n$ 
households were generally more responsive to an increase in the price of SSB compared with high-income households, with OPE (SE) reported as $-2 \cdot 20(1 \cdot 16),-3 \cdot 47$ (0.99), $-0.14(0.43),-2.95(0.52)$ and $-1.27(0.44)$ for Q1 (lowest-income quintile) to Q5 (highest-income quintile), respectively; however, the difference between quintiles 1 and 5 was not statistically significant (difference in OPE was 0.07 (95\% CI -4.71, 4.84)). Income-specific $\mathrm{CPE}$ were not reported.

\section{Modelling studies}

Seven studies used price elasticity estimates to model the impact of an SSB tax on total energy or weight outcomes (with one of these studies modelling the effect of an SSB tax on total beverage consumption ${ }^{(32)}$ ). It is important to note that such modelling allowed for possible differences in baseline SSB consumption and in the prevalence of unhealthy weight across SEP groups (both of which were generally higher for lower-income groups). Consequently, differences in price elasticity estimates across socioeconomic strata did not necessarily translate to similar differences in SSB consumption, net energy intake and/or adiposity outcomes following the examination of a hypothetical SSB tax. For example, lower price elasticity for SSB demand among groups with lower SEP (compared with higher SEP groups) may nevertheless result in a similar or greater decline in SSB consumption, net energy intake and/or adiposity outcomes for lower SEP strata, simply because baseline SSB consumption and the prevalence of excess weight are greater in this population. Six of the seven modelling studies estimated OPE in addition to an estimate of the change in demand of a related food/beverage following a change in SSB price $(\mathrm{CPE})^{(22,31-33,35,36)}$. One study used existing OPE estimates from the literature to inform the modelling analysis and did not take CPE into account ${ }^{(34)}$. The responsiveness to a change in SSB price was variable among the six studies that estimated OPE, with three studies reporting highincome households to be more price elastic ${ }^{(22,32,33)}$, two studies reporting similar price elasticity across household income categories ${ }^{(31,36)}$ and one study reporting lowincome households to be more price elastic ${ }^{(35)}$. Incomespecific substitution effects to related products (CPE) were similarly variable across studies. All six modelling studies that reported on energy intake or body weight outcomes and the one modelling study that reported on SSB purchases consistently reported similar $(n 5)^{(22,31-34)}$ or greater $(n 2)^{(22,35,36)}$ impact of an SSB tax for lowerincome groups.

Finklestein et al $^{(31)}$ modelled the impact of a $20 \%$ and $40 \%$ sales tax on either carbonated beverages or all SSB in the USA. Across all households the estimated OPE were significant and similar across income groups. OPE (SE) for carbonated beverages were $-0.73(0.09)$, with estimates ranging from $-1.02(0 \cdot 17)$ for households in the $50-75 \%$ income quartile to $-0.49(0.20)$ for households in the
0-25\% income quartile. The modelled tax on carbonated SSB significantly reduced the mean per capita beverage kilocalories purchased across the entire population by 4.2 and $7.8 \mathrm{kcal} / \mathrm{d}(17.6$ and $32.6 \mathrm{~kJ} / \mathrm{d})$ following a $20 \%$ and $40 \%$ SSB tax, respectively (taking into account both OPE and $\mathrm{CPE}$ ), which was driven entirely by middle-income households, with no statistical change reported for low- or high-income households. When extrapolating a reduction in kilocalories purchased to annual weight loss (using a static calorie-to-weight relationship), taxes on carbonated SSB of $20 \%$ and $40 \%$ generated significant annual weight losses (sE) of $0.20(0.07)$ and $0.37(0.13) \mathrm{kg}$ per person, respectively. Expanding the tax to include all SSB, it was estimated that a $20 \%$ and $40 \%$ tax would result in significantly annual weight losses of $0.32(0.09)$ and 0.59 $(0 \cdot 16) \mathrm{kg}$ per person, respectively. Again, this was driven by the middle two quartiles, with changes for households in the lowest- and highest-income quartiles not statistically significant.

Lin et $a l{ }^{(22)}$ modelled the impact of a $20 \%$ excise tax on SSB on changes in beverage consumption, net energy intake, weight loss and body weight status in the USA. OPE estimates were significant for both income groups; however, high-income demand for SSB was more price elastic than low-income demand (OPE (sE): -1.29 (0.096) and $-0.95(0.082)$ for high- and low-income groups, respectively). When the price of SSB increased, individuals from high-income households were likely to substitute SSB for skimmed milk, bottled water or juice, whereas low-income households were likely to substitute to juice only. A $20 \%$ tax on SSB translated to a larger reduction of SSB energy intake among adults from low-income households compared with adults from high-income households (a reduction of 38 and $35 \mathrm{kcal} / \mathrm{d}$ (159 and $146 \mathrm{~kJ} / \mathrm{d}$ ) for low- and high-income households, respectively). For children, a $20 \%$ tax on SSB translated to a reduction of 33 and $45 \mathrm{kcal} / \mathrm{d}(138$ and $188 \mathrm{~kJ} / \mathrm{d})$ for children from low- and high-income households, respectively. Simulating a $20 \%$ SSB tax resulted in a 1-year weight loss of $0.95 \mathrm{~kg}(1.8 \mathrm{~kg}$ at 10 years $)$ and $1.04 \mathrm{~kg}$ $(1.96 \mathrm{~kg}$ at 10 years) for high- and low-income groups, respectively (predictions not made for children).

Zhen et al. ${ }^{(32)}$ simulated the impact of a 0.5 cents per ounce $(1 \mathrm{fl}$. oz (US) $=29.574 \mathrm{ml}$ ) excise tax on SSB consumption in the USA, taking into account habit formation (estimating a myopic and rational model to account for beverage addiction). Demand for SSB was less elastic for low-income households compared with highincome households (OPE: -1.06 (rational) and -1.22 (myopic) for low-income households and -1.54 (rational) and -1.44 (myopic) for high-income households); however, high-income households were found to substitute SSB more readily than low-income households (predominantly with sports and energy drinks). This, combined with a greater baseline consumption of SSB for lower SEP groups, resulted in a similar reduction of regular 
carbonated SSB consumption for both income strata (low income: 82.81/2449 (rational) and 102.68/3037 (myopic) ounces/ml per household per month; high income: $88.92 /$ 2630 (myopic) and 92.23/2728 (rational) ounces/ml per household per month).

Briggs et al. ${ }^{(33)}$ modelled the impact of a $20 \%$ sales tax on any soft drinks with added sugar in the UK. The OPE (SE) for non-concentrated SSB were $-0.79(0 \cdot 044),-0 \cdot 80(0 \cdot 038)$ and $-0.85(0.040)$ for low-, middle- and high-income groups, respectively. For non-concentrated SSB, relatively large substitution effects occurred for non-concentrated diet soft drinks, concentrated SSB, milk, fruit juice, tea and coffee. Substitution patterns were similar across all income thirds with a trend towards larger substitution effects in the lowestincome third. The tax reduced consumption of nonconcentrated SSB by $15 \cdot 2 \%(17 \cdot 1 \mathrm{~kJ} / \mathrm{d}), 15 \cdot 9 \%(12 \cdot 4 \mathrm{~kJ} / \mathrm{d})$ and $16.8 \%(18.1 \mathrm{~kJ} / \mathrm{d})$ for the lowest-, middle- and highestincome groups, respectively. Daily net energy intake (95\% CI) was reduced by $19 \cdot 2(-29 \cdot 3,-7 \cdot 6), 13 \cdot 4(-21 \cdot 2,-4 \cdot 8)$ and $23 \cdot 2(-31 \cdot 3,-15 \cdot 0) \mathrm{kJ}$ per person for low-, middle- and highincome groups, respectively. The smaller reductions in energy intake for the low- and middle-income groups compared with the highest-income group were partly due to a greater substitution with high-fat milk; however, the confidence intervals for these estimates were wide and overlap. Corresponding reductions in mean population BMI $(95 \%$ CI) were $0.08(-0.13,-0.03), 0.06(-0.09,-0.02)$ and $0 \cdot 10(-0.13,-0.06) \mathrm{kg} / \mathrm{m}^{2}$, with no significant difference across income groups.

Briggs et al. ${ }^{(34)}$ estimated the effect of a $10 \%$ SSB excise tax on SSB purchases and consumption in Ireland. OPE were derived from the literature and were assumed to be -0.9 across all income groups. The estimated daily reduction in SSB energy intake ( $\mathrm{kcal} / \mathrm{kJ}$ per person) following a $10 \%$ SSB excise tax was $2 \cdot 2 / 9 \cdot 2$ (women) and 1.6/6.7 (men) for the lowest-income group, 1.9/7.9 (women and men) for the middle-income group and 1.9/7.9 (women) and 2.6/10.9 (men) for the highestincome group. This resulted in a similar percentage reduction $(95 \% \mathrm{CI})$ in the prevalence of obesity across income groups, which was $1.4(1.0,1.9)$ for women and $0.7(0.5,1 \cdot 0)$ for men in the lowest-income group, $1 \cdot 2(0.8$, 1.6) for women and $1.0(0.7,1.3)$ for men in the middleincome group and $1.2(0 \cdot 8,1 \cdot 6)$ for women and $1 \cdot 5(1 \cdot 0,1 \cdot 9)$ for men in the highest-income group.

Sharma et al. ${ }^{(35)}$ modelled the effect of a $20 \%$ sales tax and a 20 cents per litre excise tax on SSB consumption, net energy reduction and body weight by household income level in Australia. Following a $20 \%$ SSB sales tax, the demand for regular soft drinks was estimated to be slightly less responsive for high-income households (a significant per capita reduction of $13 \cdot 10 \%$ (35.17 ounces $(1040 \mathrm{ml})$ / quarter), $14.92 \%(50.7$ ounces $(1499 \mathrm{ml}) /$ quarter $)$ and $15.05 \%(52 \cdot 1$ ounces $(1541 \mathrm{ml})$ /quarter $)$ for high-, middleand low-income households, respectively; significant differences between income groups not tested). Differences across income groups were more pronounced for fruit drinks (a significant reduction of $11.82 \%, 36.61 \%$ and $3.08 \%$ for high-, middle- and low-income households, respectively) and cordial (45.55\%, 35.63\% and $29.98 \%$ for high-, middle- and low-income households, respectively). A $20 \%$ sales tax resulted in a reduction in body weight for all income groups, which was significantly greatest for those with the lowest compared with highest incomes $(0.40 \mathrm{~kg}$ compared with $0.37 \mathrm{~kg}$ for middle-income and $0.23 \mathrm{~kg}$ for high-income groups). This was a result of greater price elasticity and greater baseline consumption of SSB for lower-income groups. A 20 cents per litre tax resulted in a reduction in weight of $0.56,0.69$ and $0.35 \mathrm{~kg}$ for low-, middle- and high-income households, respectively.

Zhen et $a l .{ }^{(36)}$ estimated the impact of a 0.5 cents per ounce SSB excise tax (approximating an average increase in retail SSB price of $26 \%$ ) on US household purchases of energy and on the nutrients fat and sodium. OPE for regular carbonated soft drinks for high- and low-income households were similar $(-1.03$ and -1.04 for low- and high-income households, respectively). CPE were also broadly similar across income groups. Across all households, Zhen et al. estimated that this tax would reduce per capita daily energy intake by $13.2 \mathrm{kcal}(55 \cdot 2 \mathrm{~kJ})$ for lowincome households and by $5.6 \mathrm{kcal}(23.4 \mathrm{~kJ})$ for highincome households. Using a dynamic energy-weight loss model, these reductions in energy intake were estimated to translate to reductions in weight of 0.37 and $0.16 \mathrm{~kg} /$ person in 1 year and 0.70 and $0.31 \mathrm{~kg} /$ person in 10 years for low- and high-income households, respectively (the significance of these estimates was not tested).

\section{Amount paid in sugar-sweetened beverage tax according to socio-economic position following an increase in sugar-sweetened beverage price}

Five of the studies included in the current review examined the amount paid in tax following an increase in the price of SSB by $\operatorname{SEP}^{(22,32,33,35,36)}$. All of these studies reported the tax to be financially regressive whereby lower-income households would pay a greater proportion of their income in additional tax. Results for each study are described below. For comparison across studies, the difference in SSB tax paid between the highest- and lowestincome households are also presented annually and in \$US using 2015 conversion rates.

Lin et $a{ }^{(22)}$ reported, across all household income groups, that the tax burden following a $20 \%$ SSB excise tax would represent a small share of the total food and beverage budget, at less than $1 \%$ of annual food and beverage spending. Low-income households, who consume more SSB, would pay slightly more in annual tax (\$US 19.97; $1 \%$ of annual food budget) compared with high-income households (\$US 18.84; 0.6\% of annual food budget). Zhen et $a{ }^{(32)}$ estimated that low-income households would pay an annual tax of \$US 17.64-18.60 (approximately $0 \cdot 1 \%$ of annual household income) and 
high-income households an annual tax of \$US 15.84-16.92 (approximately $0.03 \%$ of annual household income) following a 0.5 cents per ounce excise tax on SSB. Following a $20 \%$ sales tax on SSB, Briggs et al. ${ }^{(33)}$ reported the greatest increase in beverage expenditure for the lowest-income group (increase $(95 \% \mathrm{CI})$ of $9.4(6 \cdot 2,13.4)$ p per person per week; $2 \cdot 1(1 \cdot 4,3 \cdot 0) \%)$ compared with the middle-income group (increase of $9 \cdot 1(6 \cdot 6,11.9)$ p per person per week; $1 \cdot 7(1 \cdot 2,2 \cdot 2) \%)$ and the high-income group (increase of $6 \cdot 0(3 \cdot 2,8 \cdot 8) \mathrm{p}$ per person per week; $0.8(0.4,1.2) \%)$. This represented a difference in the annual amount paid in SSB tax of less than \$US 2.5 between high- and low-income households. Sharma et $a .^{(35)}$ estimated that following a $20 \%$ sales tax, low-income households would pay approximately \$AU 20.89 per capita per year in SSB tax $(0.22 \%$ of annual household income) compared with \$AU 17.74 (0.07\% of annual household income) and \$AU 16.60 (0.02\% of annual household income) for middle- and high-income households, respectively, with significant differences between the highest- and lowest-income groups. The tax burden would be lower for a 20 cents per litre excise tax, at \$AU 19.00, \$AU 14.77 and \$AU 13.81 per annum, representing $0 \cdot 15 \%, 0.05 \%$ and $0.04 \%$ of annual household income for low-, middle- and high-income households, respectively. When converted to \$US, for both of the modelled taxes, the difference in the annual amount paid in SSB tax between high- and low-income households was less than \$US 4 . Zhen et al. ${ }^{(36)}$ estimated that a 0.5 cents per ounce increase in SSB would result in low-income households paying approximately \$US 5 per household per year more in SSB tax compared with highincome households, with an average of \$US 20 paid in SSB tax per household per year.

\section{Discussion}

The current review synthesises all existing literature on beverage purchase, consumption and weight outcomes, and the amount paid in SSB tax, following an increase in SSB price or an SSB tax across socio-economic strata within high-income countries. We found consistent evidence that a tax on SSB is likely to lead to improvements in population weight of a similar magnitude across SEP groups or of a greater magnitude for lower compared with higher SEP groups. Our review reinforces the regressive financial nature of an SSB tax, whereby lowerincome households would pay a greater proportion of their income in additional tax; however, the monetary burden across all households is small, with relatively minor differences between higher- and lower-income households $(0 \cdot 10-1 \cdot 0 \%$ and $0.03-0.60 \%$ of annual household income paid in SSB tax for low- and highincome households, respectively, equating to less than \$US 5 per year). This challenges the significance of the financial regressivity argument commonly put forth to oppose such a tax ${ }^{(23)}$. The findings from the present review are important as countries begin to consider, and indeed implement, this policy around the world.

Our results corroborate those of a 2012 systematic review of simulation studies examining the association between food and beverage pricing strategies and changes in purchase or consumption of food and beverage items and health-related outcomes ${ }^{(25)}$. Similarly, our results align with those of Thow et al. ${ }^{(26)}$ (2014) who systematically reviewed the literature for studies that reported the effect of food and beverage taxes and subsidies on food and beverage consumption. When extracting the data pertaining to SSB, both these reviews concluded that the relative health benefits inferred following a price increase on SSB, or a tax on SSB, were greater for consumers of lower (compared with higher) income. Our review updates and extends these reviews by including studies of all designs and reporting on all differential impacts of an SSB tax or price change for a range of outcomes across the intended policy pathway of effect according to SEP (rather than including it as a small subsection within a broader review). We additionally summarise the amount paid in SSB tax for each SEP group, which has not been reported in prior reviews. While the variation in outcomes reported within our review and the differences in the type and size of tax (or price increase) examined precluded synthesis to a single summary effect, it allowed the inclusion of a much broader range of studies, all of which were able to contribute to our conclusion that an SSB tax is likely to have a similar effect on population weight across socio-economic strata or a greater impact for lower SEP groups.

The recent evaluation of the national SSB tax policy in Mexico on the purchase of SSB across different socio-economic groups supports the conclusions from our review herein. One year post implementation of the policy in January 2014, which required an increase in the price of SSB at a rate of one peso per litre (roughly equivalent to a $10 \%$ increase in price), there was a reduction in mean SSB purchases across all socio-economic groups, with the greatest reduction among households with the lowest resources (SSB purchases reduced by $17 \%$ one year after policy implementation in this group compared with $12 \%$ overall $^{(20)}$. In the current review we excluded low- to middle-income countries due to the varied and often reverse relationship between SEP and SSB consumption and/or obesity prevalence ${ }^{(37)}$, and thus the likelihood that the equity impact of a tax on SSB may also differ. While Mexico is considered a middle-income country, and data from the 2006 Mexican Household Income and Expenditure Survey indeed reveal a positive relationship between SEP and energy intake from soda ${ }^{(38)}$, these recent results of the impact of the national SSB tax policy are nevertheless congruent with results in our review on high-income countries, where the relationship between SEP and SSB purchase and consumption is reversed. 
OPE, and the difference across income groups, were variable across the eight studies that reported incomespecific estimates. This variation in OPE estimates across different studies is likely to result from methodological variations (including data sources used, beverage grouping and/or model specifications used to estimate price elasticities) or real country and contextual differences in response to an SSB price change. Understanding the exact sources of variation will be important to inform the evidence base on the likely impact of an SSB tax on population weight. Nevertheless, when studies used price elasticity estimates to simulate the effect of a hypothetical SSB tax on total energy intake and/or health outcomes, results were remarkably consistent across studies, with all studies demonstrating either a similar benefit across households with differing income levels or a greater impact for households with a lower compared with higher income. The impact of an SSB tax on population weight results from a delicate balance between OPE, CPE (product substitution), and the distribution of SSB consumption and weight within a population. While modelling studies have their limitations, they are able to account for these determinants (to a greater or lesser degree, depending on the study). Eight of the eleven studies included in our review reported greater SSB consumption and higher weight and/or obesity prevalence for lowerincome households, with mixed reports of differential product compensation across income groups. These results highlight that caution should be taken when concluding on the health equity impact of an SSB tax based on price elasticity data alone.

\section{Strengths and limitations of the study}

The strengths of the current study include the comprehensive systematic search of both academic and grey literature and extraction of all relevant data by at least two authors.

The major limitation relates to the limited variability in study types identified. Only three studies evaluated the association between existing real-world SSB taxes and SSB consumption or weight outcomes, and these studies were all limited by the relatively small tax rates (average of approximately $4 \%$ ) and the limited variability in taxes across US states. The remaining eight studies estimated price elasticities of SSB demand and seven of these simulated the effects of an SSB tax on total SSB consumption, total energy intake or weight outcomes using econometric modelling methods. These latter studies are reliant on household survey or scanner data and a number of assumptions, which may not have been empirically tested. These studies do not consider 'real-world' dynamics, such as the interaction of pricing strategies with other population- or individual-level interventions, the impact on social norms as a result of implementing a 'healthrelated' tax, possible unintended consequences and the response from the beverage industry, all of which could have a differential impact according to SEP. Furthermore, only six of studies considered the differential impact of substituting SSB with other beverages and only one considered substitution to food products. As the overall health impact of an SSB tax depends on the net change in energy intake from all foods and beverages it is important to consider all possible substitutions, which may differ according to socio-economic group. For example, Zhen et $a l .{ }^{(36)}$ estimated that almost half of the reduction in SSB kilocalories caused by an increase in its price could be offset by an increase in kilocalories from other foods, with a probable increase in sodium and fat intake. This highlights the complexity of evaluating the impact of a tax on SSB and the need to consider possible unintended effects across all socio-economic groups. While our conclusions herein remain robust, it is essential that they are confirmed with other study designs. For this reason, as SSB taxation policies are implemented around the world, as they have been recently in Mexico and St Helena, it is important that they are rigorously evaluated with the data disaggregated by SEP. Nevertheless, while real-world evaluations have great external validity, internal validity is difficult to manage. It may therefore also be important that experimental studies be conducted and the conclusion on the health equity impact of a tax on SSB be based on the totality of evidence, as recommended by the US body, the Institute of Medicine ${ }^{(39)}$.

A further limitation is that many of the included studies did not evaluate if the differences in outcomes were significantly different between groups of differing SEP. While this is unlikely to alter our conclusions that an SSB tax is unlikely to increase socio-economic inequalities in weight, we recommend future studies statistically test differences across socio-economic groups.

SSB have been linked to a number of non-communicable diseases, including CVD $^{(13)}$ and diabetes ${ }^{(40)}$ as well as dental caries $^{(41)}$, all of which are more prevalent among lower SEP groups in high-income countries ${ }^{(42-44)}$. Thus, it is likely that the health equity benefits of a tax on SSB extend beyond the weight outcomes described in the present review. Furthermore, if the revenue generated from the tax was directed towards targeted interventions that improved health among more disadvantaged groups, then the health equity impact of an SSB tax may be greater. A tax on SSB should be considered as just one strategy among many to address the unequal burden of excess weight and health across socioeconomic groups.

\section{Conclusion}

Current evidence suggests that a tax on SSB is likely to be an effective policy to reduce SSB consumption ${ }^{(25,26)}$. Here we additionally demonstrate that, within the current evidence base, a tax on SSB is also likely to have a similar impact on consumption and weight outcomes 
for high- and low-income households or a greater impact among those with a lower SEP. Our evidence synthesis further challenges the relevance of the argument pertaining to financial regressivity. Careful health equity evaluations of real-world SSB taxation policies and wellcontrolled experimental studies are required to broaden and strengthen the evidence base in this area.

\section{Acknowledgements}

Financial support: This work was supported by the Australian Research Council (Linkage Project Grant 120100418) and the Australian National Preventive Health Agency (188PEE2011) and in part by the Victorian Government's Operational Infrastructure Support (OIS) Program. K.B. was supported by a Post-doctoral Research Fellowship from the National Heart Foundation of Australia (PH 12M 6824). A.P. was supported by a National Health and Medical Research Council Career Development Fellowship (ID 1045456). K.B. was supported by a National Health and Medical Research Council Principal Research Fellowship (ID 1042442). The funders had no role in the design, analysis or writing of this article. Conflict of interest: None. Authorship: K.B. and A.P. designed the study. K.B. conducted the search, extracted data and wrote the manuscript. D.S., A.B., C.K. and V.L. extracted data and reviewed the manuscript. K.B. and J.M. reviewed the manuscript. Ethics of human subject participation: Not applicable.

\section{Supplementary material}

To view supplementary material for this article, please visit http://dx.doi.org/10.1017/S136898001600104X

\section{References}

1. Backholer K, Mannan HR, Magliano DJ et al. (2012) Projected socioeconomic disparities in the prevalence of obesity among Australian adults. Aust N Z J Public Health 36, 557-563.

2. Ball K \& Crawford D (2005) Socioeconomic status and weight change in adults: a review. Soc Sci Med 60, 1987-2010.

3. Marmot M (2010) Fair Society, Healthy Lives. London: The Marmot Review.

4. Beauchamp A, Backholer K, Magliano D et al. (2014) The effect of obesity prevention interventions according to socioeconomic position: a systematic review. Obes Rev $\mathbf{1 5}$, 541-554.

5. Magnee T, Burdorf A, Brug J et al. (2013) Equity-specific effects of 26 Dutch obesity-related lifestyle interventions. Am J Prev Med 44, e57-e66.

6. Hillier-Brown FC, Bambra CL, Cairns JM et al. (2014) A systematic review of the effectiveness of individual, community and societal level interventions at reducing socioeconomic inequalities in obesity amongst children. BMC Public Health 14, 834.

7. Hillier-Brown FC, Bambra CL, Cairns JM et al. (2014) A systematic review of the effectiveness of individual, community and societal-level interventions at reducing socio-economic inequalities in obesity among adults. Int $J$ Obes (Lond) 38, 1483-1490.

8. Institute of Medicine (2012) Accelerating Progress in Obesity Prevention: Solving the Weight of the Nation. Washington, DC: The National Academies Press.

9. National Preventative Health Taskforce (2009) Australia: The Healthiest Country by 2020. Canberra: Commonwealth of Australia.

10. Brownell KD \& Frieden TR (2009) Ounces of prevention the public policy case for taxes on sugared beverages. N Engl J Med 360, 1805-1808.

11. Brownell KD, Farley T, Willett WC et al. (2009) The public health and economic benefits of taxing sugar-sweetened beverages. $N$ Engl J Med 361, 1599-1605.

12. Vartanian LR, Schwartz MB \& Brownell KD (2007) Effects of soft drink consumption on nutrition and health: a systematic review and meta-analysis. Am J Public Health 97, 667-675.

13. Malik VS, Popkin BM, Bray GA et al. (2010) Sugarsweetened beverages, obesity, type 2 diabetes mellitus, and cardiovascular disease risk. Circulation 121, $1356-1364$.

14. Mourao DM, Bressan J, Campbell WW et al. (2007) Effects of food form on appetite and energy intake in lean and obese young adults. Int J Obes (Lond) 31, 1688-1695.

15. DiMeglio DP \& Mattes RD (2000) Liquid versus solid carbohydrate: effects on food intake and body weight. Int J Obes Relat Metab Disord 24, 794-800.

16. Mullie P, Aerenhouts D \& Clarys P (2012) Demographic, socioeconomic and nutritional determinants of daily versus non-daily sugar-sweetened and artificially sweetened beverage consumption. Eur J Clin Nutr 66, 150-155.

17. van Ansem WJ, van Lenthe FJ, Schrijvers CT et al. (2014) Socio-economic inequalities in children's snack consumption and sugar-sweetened beverage consumption: the contribution of home environmental factors. Br J Nutr 112, 467-476.

18. Kumar G, Pan L, Park S et al. (2014) Sugar-sweetened beverage consumption among adults - 18 states, 2012. MMWR Morb Mortal Wkly Rep 63, 686-690.

19. Kim B \& Rossi P (1994) Purchase frequency, sample selection, and price sensitivity: the heavy-user bias. Mark Lett 5, 57-67.

20. Colchero MA, Popkin BM, Rivera JA et al. (2016) Beverage purchases from stores in Mexico under the excise tax on sugar sweetened beverages: observational study. BMJ 352, h6704.

21. Andreyeva T, Long MW \& Brownell KD (2010) The impact of food prices on consumption: a systematic review of research on the price elasticity of demand for food. $A m J$ Public Health 100, 216-222.

22. Lin BH, Smith TA, Lee JY et al. (2011) Measuring weight outcomes for obesity intervention strategies: the case of a sugar-sweetened beverage tax. Econ Hum Biol 9, 329-341.

23. Mytton OT, Clarke D \& Rayner M (2012) Taxing unhealthy food and drinks to improve health. BMJ 344, e2931.

24. Welch V, Petticrew M, Tugwell P et al. (2012) PRISMAEquity 2012 extension: reporting guidelines for systematic reviews with a focus on health equity. PLoS Med 9, e1001333.

25. Eyles H, Ni Mhurchu C, Nghiem N et al. (2012) Food pricing strategies, population diets, and non-communicable disease: a systematic review of simulation studies. PLoS Med $\mathbf{9}$, e1001353.

26. Thow AM, Downs S \& Jan S (2014) A systematic review of the effectiveness of food taxes and subsidies to improve diets: understanding the recent evidence. Nutr Rev 72, 551-565.

27. Powell LM, Chriqui J \& Chaloupka FJ (2009) Associations between state-level soda taxes and adolescent body mass index. J Adolesc Health 45, 3 Suppl., S57-S63. 
28. Sturm R, Powell LM, Chriqui JF et al. (2010) Soda taxes, soft drink consumption, and children's body mass index. Health Aff (Millwood) 29, 1052-1058.

29. Fletcher JM, Frisvold D \& Tefft N (2010) Can soft drink taxes reduce population weight? Contemp Econ Policy 28, 23-35.

30. Ni Mhurchu C, Eyles H, Schilling C et al. (2013) Food prices and consumer demand: differences across income levels and ethnic groups. PLoS One 8, e75934.

31. Finkelstein EA, Zhen C, Nonnemaker J et al. (2010) Impact of targeted beverage taxes on higher- and lower-income households. Arch Intern Med 170, 2028-2034.

32. Zhen C, Wohlgenant M, Karns S et al. (2011) Habit formation and demand for sugar-sweetened beverages. Am J Agric Econ 93, 175-193.

33. Briggs AD, Mytton OT, Kehlbacher A et al. (2013) Overall and income specific effect on prevalence of overweight and obesity of $20 \%$ sugar sweetened drink tax in UK: econometric and comparative risk assessment modelling study. BMJ 347, f6189.

34. Briggs AD, Mytton OT, Madden D et al. (2013) The potential impact on obesity of a $10 \%$ tax on sugar-sweetened beverages in Ireland, an effect assessment modelling study. BMC Public Health 13, 860.

35. Sharma A, Hauck K, Hollingsworth B et al. (2014) The effects of taxing sugar-sweetened beverages across different income groups. Health Econ 23, 1159-1184.

36. Zhen C, Finkelstein EA, Nonnemaker J et al. (2014) Predicting the effects of sugar-sweetened beverage taxes on food and beverage demand in a large demand system. $A m J$ Agric Econ 96, 1-25.
37. Peeters A, Walls HL, Backholer K et al. (2015) Welcome from the policies, socio-economic aspects, and health systems research section. BMC Obes $\mathbf{2}, 23$.

38. Barquera S, Hernandez-Barrera L, Tolentino ML et al. (2008) Energy intake from beverages is increasing among Mexican adolescents and adults. $J$ Nutr 138, 2454-2461

39. Institute of Medicine (2010) Bridging the Evidence Gap in Obesity Prevention: A Framework to Inform Decision Making. Washington, DC: The National Academies Press.

40. Malik VS, Popkin BM, Bray GA et al. (2010) Sugarsweetened beverages and risk of metabolic syndrome and type 2 diabetes: a meta-analysis. Diabetes Care 33, 2477-2483.

41. Moynihan PJ \& Kelly SA (2014) Effect on caries of restricting sugars intake: systematic review to inform WHO guidelines. $J$ Dent Res 93, 8-18.

42. Williams ED, Tapp RJ, Magliano DJ et al. (2010) Health behaviours, socioeconomic status and diabetes incidence: the Australian Diabetes Obesity and Lifestyle Study (AusDiab). Diabetologia 53, 2538-2545.

43. Beauchamp A, Peeters A, Wolfe R et al. (2010) Inequalities in cardiovascular disease mortality: the role of behavioural, physiological and social risk factors. $J$ Epidemiol Community Health 64, 542-548.

44. Capurro DA, Iafolla T, Kingman A et al. (2015) Trends in income-related inequality in untreated caries among children in the United States: findings from NHANES I, NHANES III, and NHANES 1999-2004. Community Dent Oral Epidemiol 43, 500-510. 